\title{
Low birthweight infants and total parenteral nutrition immediately after birth. I. Energy expenditure and respiratory quotient of ventilated and non-ventilated infants
}

\author{
J S Forsyth, A Crighton
}

\begin{abstract}
The aim of this study was to determine the energy expenditure and respiratory quotient (RQ) of ventilated and nonventilated low birthweight infants during the first five days of life, in order to determine optimal feeding regimens. Eighty six infants, of birthweight less than $1750 \mathrm{~g}$, were grouped according to whether they were artificially ventilated or breathing air spontaneously, and whether they were parenterally or enterally fed at the time of study. Energy expenditure and respiratory quotient were measured during days 1-5 and the relation of energy expenditure to several explanatory variables was investigated using multiple regression analysis. The energy expenditure of ventilated infants was less than that of spontaneously breathing infants; the differences were significant on days 1-3. The respiratory quotient (mean (SE)) was greater in intravenously fed infants compared with milk-fed $-0.99(0.03) v 0.92$ (0.01) $(P<0.05)$, with $42 \%$ of studies of infants receiving total parenteral nutrition (TPN) producing an RQ of $>1.0 \mathrm{com}-$ pared with $16.6 \%$ of milk-fed infants $(\mathbf{P}<0 \cdot 01)$. There was a significant correlation between glucose intake and $R Q$ $(\mathbf{r}=0.39, \quad P<0.001)$. The activity scores were measured during 75 studies and scores were significantly higher in spontaneously breathing milk-fed infants compared with ventilated parenterally fed infants. Factors independently related to energy expenditure were: postnatal age $(P<0.01)$; milk feeds $(P<0.01)$; and physical activity $(P<0.05)$.
\end{abstract}

A mix of carbohydrate and fat from day 1 may not only meet energy needs but may also reduce respiratory quotient. (Arch Dis Child 1995; 73: F4-F7)

Keywords: total parenteral nutrition, low birthweight infant, energy expenditure, respiratory quotient.

Optimal nutrition during the immediate postnatal period will not only enhance the physical growth of the infant but may also enable greater fulfilment of intellectual potential. ${ }^{1}$ Infants at greatest risk of nutritional insufficiency during the newborn period are the most sick and the most premature. These infants may not tolerate enteral nutrition and need to be fed by the parenteral route. It has been traditional practice cautiously to introduce amino acid solutions and fat emulsions towards the end of the first week of life to prevent intolerance and other potential side effects. ${ }^{2}$ A consequence of this approach is that the metabolic and growth demands of these infants are unlikely to be met during the first days of life. ${ }^{3}$ With recent evidence indicating that infants have critical periods of development which can be adversely influenced by relatively brief periods of nutritional deprivation, ${ }^{4}$ the practice of limiting the nutritional intake during the first days of life may not be beneficial to the infant.

If a more optimal feeding regimen for these infants is to be prescribed, further data on those factors which may significantly influence energy expenditure and nutrient utilisation of sick ventilated infants during the immediate postnatal period are required. Hitherto, availability of these data have been limited because of technical and methodological difficulties, but we have recently developed and evaluated an indirect calorimetry system for preterm ventilated infants. ${ }^{5}$ The aim of this study was to determine the energy expenditure and respiratory quotient of ventilated and nonventilated low birthweight infants during the first five days of life, relating the findings to relevant nutritional and non-nutritional factors.

\section{Methods}

Eighty six infants admitted to the Neonatal Unit in Ninewells Hospital with a birthweight between the 3rd and 97th centile and less than $1750 \mathrm{~g}$, were entered into the study. The infants were recruited according to whether they were artificially ventilated or breathing air spontaneously, and whether they were parenterally or enterally fed at the time of study. In this study no attempt was made to standardise 
Table 1 Characteristics of infants in each study group

\begin{tabular}{lllll}
\hline Group & $n=$ & $\begin{array}{l}\text { Gestation } \\
\text { (weeks) }\end{array}$ & $\begin{array}{l}\text { Birthweight } \\
(g)\end{array}$ \\
\hline 1 & Ventilated infants receiving TPN & 27 & $29 \cdot 3(0 \cdot 4)$ & $1199(53 \cdot 5)$ \\
2 Non-ventilated infants receiving TPN & 37 & $31 \cdot 5(0 \cdot 5)$ & $1279(44 \cdot 1)$ \\
3 Non-ventilated infants receiving milk feeds & 22 & $32 \cdot 7(0 \cdot 4)^{\star \star}$ & $1495(37 \cdot 6)^{\star \star}$ \\
\hline
\end{tabular}

Indices: mean (SE). Groups $1 v 2 v 3 .{ }^{\star \star} \mathrm{P}<0.001$.

care between study groups, but infants requiring surgical treatment were excluded. Routine medical and nursing care were provided as clinically indicated.

Indirect calorimetry was performed, as described before for ventilated infants ${ }^{5}$ and for spontaneously air breathing infants, ${ }^{6}$ for a minimum of 90 minutes between the times of 0900 and 1300 hours. The calorimetry systems provide real time measurements of inspiratory and expiratory oxygen and carbon dioxide concentrations and ventilator flow rate, from which oxygen consumption and carbon dioxide production, respiratory quotient, and energy expenditure are calculated. ${ }^{7}$ Respiratory quotient (RQ) is the ratio of carbon dioxide production to oxygen consumption and indicates the nature of substrates being metabolised. The RQ may vary from 0.7 if fat is the sole substrate being metabolised, to 1.0 for carbohydrate utilisation. An RQ greater than 1.0 indicates that excess carbohydrate is being converted to fat.

Blood gas exchange was monitored throughout the study period by measurement of arterial or capillary $\mathrm{PO}_{2}$ and $\mathrm{PCO}_{2}$. The ventilator settings of inspired oxygen concentration $\left(\mathrm{FIO}_{2}\right)$ expressed as $0 \cdot 21-1 \cdot 0$, ventilator rate (breaths/minute), peak inspiratory pressure (PIP), and positive end expiratory pressure (PEEP) in $\mathrm{cm} \mathrm{H}_{2} \mathrm{O}$ were recorded. For infants receiving artificial ventilation the ventilator index (VIN) was calculated: $\mathrm{VIN}=$ mean airway pressure $\times \mathrm{FiO}_{2} / \mathrm{PaO}_{2} \cdot{ }^{8}$ Sedatives and paralysing agents are not routinely prescribed for this group of infants and those infants who did require regular sedation or muscle relaxant were excluded from the analysis.

Infants receiving intravenous fluids were initially commenced on an infusion of glucose $10 \%(80 \mathrm{ml} / \mathrm{kg} /$ day $)$ and amino acids and lipid emulsion were introduced gradually from the second and third days of life, respectively. By day 5 infants were receiving about $150 \mathrm{ml} /$ $\mathrm{kg} /$ day (13.3 $\mathrm{g}$ glucose, $2 \mathrm{~g}$ amino acid, and $3.4 \mathrm{~g} \mathrm{fat} / \mathrm{kg} /$ day). During the first 48 hours of life the enterally fed infants received some intravenous fluid in addition to the milk feed and calorimetry was therefore withheld until day 3 when all infants in this group were fully milk fed. By day 5 they received about $150 \mathrm{ml}$ $\mathrm{kg} /$ day of expressed breast milk or low birthweight formula (Cow \& Gate/Nutricia Ltd, Trowbridge, Wiltshire, England) given by nasogastric bolus feeds every one to three hours.

During the calorimetry studies, infant activity was recorded using a previously reported modification of Brück's activity scales. ${ }^{9}$

The means (SE) of the groups were compared using either unpaired $t$ tests or analysis of variance. The relation of energy expenditure to several explanatory variables was investigated using multiple regression analysis.

This study was approved by the Tayside Ethics Committee and informed consent was obtained from the parent or guardian of the infant.

\section{Results}

Characteristics of the infants recruited to the study are shown in table 1. Data from this study were treated cross-sectionally and table 2 compares the mean birthweight, mean gestation, and number of studies in each of the study groups on days $1-5$. The ventilator requirements of the ventilator-dependent group during calorimetry and the differences in $\mathrm{PaO}_{2}$ and $\mathrm{PCO}_{2}$ recorded at the beginning and the end of the calorimetry period are shown in table 3. Energy intake and energy expenditure are shown in table 4 . The energy expenditure of ventilated infants was less than that of spontaneously breathing infants, the differences being most significant on days 1 to 3 . Measurements of $\mathrm{VO}_{2}, \mathrm{VCO}_{2}$ and $\mathrm{RQ}$ in each of the three groups are shown in table 5 . There were significant differences between groups for $\mathrm{VO}_{2}$ during the first four days of life and for $\mathrm{VCO}_{2}$ during the first two days. The RQ was greater in intravenously fed infants compared with milk fed infants: $0.99(0.03) v 0.92(0.01)$ $(P<0.05)$, with $42 \%$ of studies of infants receiving TPN producing an $R Q$ of $>1.0 \mathrm{com}$ pared with $16.6 \%$ of milk fed infants $(P<0.01)$. There was a significant correlation between glucose intake and RQ $(r=0 \cdot 49$, Sy.x $2 \cdot 22$ ). The activity scores were measured over 75 studies and scores were significantly higher in spontaneously breathing milk fed infants compared than in ventilated parenterally fed infants (table 6).

As this was not a controlled study and there was considerable inter- and intra-individual variation in the measured levels of energy expenditure, multiple regression analysis was

Table 2 Characteristics and numbers of infants on study days 1-5

\begin{tabular}{|c|c|c|c|c|c|c|c|c|c|}
\hline \multirow[b]{2}{*}{ Day } & \multicolumn{3}{|c|}{ Group 1} & \multicolumn{3}{|c|}{ Group 2} & \multicolumn{3}{|c|}{ Group 3} \\
\hline & $\begin{array}{l}\text { No of } \\
\text { studies }\end{array}$ & $\begin{array}{l}\text { Gestation } \\
\text { (weeks) }\end{array}$ & $\begin{array}{l}\text { Weight } \\
(g)\end{array}$ & $\begin{array}{l}\text { No of } \\
\text { studies }\end{array}$ & $\begin{array}{l}\text { Gestation } \\
\text { (weeks) }\end{array}$ & $\begin{array}{l}\text { Weight } \\
(g)\end{array}$ & $\begin{array}{l}\text { No of } \\
\text { studies }\end{array}$ & $\begin{array}{l}\text { Gestation } \\
\text { (weeks) }\end{array}$ & $\begin{array}{l}\text { Weight } \\
(g)\end{array}$ \\
\hline $\begin{array}{l}1 \\
2 \\
3 \\
4 \\
5\end{array}$ & $\begin{array}{r}8 \\
9 \\
8 \\
11 \\
10\end{array}$ & $\begin{array}{l}29.8(0.6) \\
28.5(0.6) \\
28.9(0.7) \\
28.7(0.5) \\
29.2(0.7)\end{array}$ & $\begin{array}{l}1215(98) \\
1183(106) \\
1201(106) \\
1176(86) \\
1107(81)\end{array}$ & $\begin{array}{r}16 \\
14 \\
8 \\
8 \\
8\end{array}$ & $\begin{array}{l}30.67(0.4) \\
31 \cdot 6(0 \cdot 4)^{\star \star} \\
31 \cdot 3(0 \cdot 8) \\
32 \cdot 1(0.9) \\
33 \cdot 1(1.0)\end{array}$ & $\begin{array}{l}1249(39) \\
1221(37) \\
1301(88) \\
1268(111) \\
1368(146)\end{array}$ & $\begin{array}{l}8 \\
8 \\
7\end{array}$ & $\begin{array}{l}32.3(0.8)^{\star} \\
33.9(0.6)^{\star \star} \\
34 \cdot 1(0.8)^{\star \star}\end{array}$ & $\begin{array}{l}1523(55)^{\star} \\
1543(63)^{\star} \\
1575(68)^{\star}\end{array}$ \\
\hline
\end{tabular}

Indices: mean (SE). Days 1-2: groups $1 v 2 \star \star P<0.001$; days 3-5: groups $1 v 2 v 3{ }^{\star} P<0.01, \star \star P<0.001$. 
Table 3 Ventilator requirements for infants in group 1 and differences in $\mathrm{PaO}_{2}$ and $\mathrm{PACO}_{2}$ recorded before and after calorimetry

\begin{tabular}{|c|c|c|c|c|c|}
\hline Day & $\begin{array}{l}\text { Rate } \\
\text { (breaths/minute) }\end{array}$ & $\mathrm{FIO}_{2}$ & $\begin{array}{l}\mathrm{PIP} \\
\left(\mathrm{cm} \mathrm{H}_{2} \mathrm{O}\right)\end{array}$ & $\begin{array}{l}\text { Mean difference } \\
\mathrm{PaO}_{2}(\mathrm{kPa})\end{array}$ & $\begin{array}{l}\text { Mean difference } \\
\mathrm{PaCO}_{2}(\mathrm{kPa})\end{array}$ \\
\hline $\begin{array}{l}1 \\
2 \\
3 \\
4 \\
5\end{array}$ & $\begin{array}{l}27 \cdot 6(2 \cdot 4) \\
25 \cdot 8(4 \cdot 7) \\
27 \cdot 3(2 \cdot 4) \\
25 \cdot 5(4 \cdot 9) \\
17 \cdot 4(3 \cdot 6)\end{array}$ & $\begin{array}{l}0.34(0.04) \\
0.32(0.04) \\
0.30(0.03) \\
0.30(0.02) \\
0.23(0.01)\end{array}$ & $\begin{array}{l}19.6(0.5) \\
19.0(0.7) \\
19.6(0.7) \\
19.1(0.7) \\
18.6(0.8)\end{array}$ & $\begin{array}{c}0.35(0.7) \\
-0.43(0.8) \\
-0.3(0.6) \\
-0.7(0.4) \\
0.1(0.4)\end{array}$ & $\begin{array}{r}-0.08(0.4) \\
0.59(0.3) \\
-0.46(0.5) \\
-0.47(0.3) \\
-0.20(0.3)\end{array}$ \\
\hline
\end{tabular}

Indices: mean (SE).

Table 4 Energy intake (EI) and expenditure (EE) during days 1-5

\begin{tabular}{|c|c|c|c|c|c|c|}
\hline \multirow[b]{2}{*}{ Day } & \multicolumn{2}{|l|}{ Group 1} & \multicolumn{2}{|l|}{ Group 2} & \multicolumn{2}{|l|}{ Group 3} \\
\hline & $\begin{array}{l}E E \\
(\text { kcal/kg/d) }\end{array}$ & $\begin{array}{l}E I \\
(k c a l / k g / d)\end{array}$ & $\begin{array}{l}E E \\
(\text { kcal/kg/d) }\end{array}$ & $\begin{array}{l}E I \\
(k c a l / k g / d)\end{array}$ & $\begin{array}{l}E E \\
(k c a l / k g / d)\end{array}$ & $\begin{array}{l}E I \\
(k c a l / k g / d)\end{array}$ \\
\hline $\begin{array}{l}1 \\
2 \\
3 \\
4 \\
5\end{array}$ & $\begin{array}{l}35 \cdot 5(1 \cdot 6) \\
37.0(2 \cdot 2) \\
40 \cdot 8(2 \cdot 5) \\
40 \cdot 3(2 \cdot 7) \\
42.9(2 \cdot 0)\end{array}$ & $\begin{array}{l}33 \cdot 8(2 \cdot 1) \\
35 \cdot 2(3 \cdot 9) \\
53 \cdot 8(4 \cdot 7) \\
52 \cdot 9(4 \cdot 9) \\
76 \cdot 3(7 \cdot 1)\end{array}$ & $\begin{array}{l}41 \cdot 5(1 \cdot 6)^{\star} \\
44 \cdot 5(1 \cdot 5)^{\star \star} \\
42 \cdot 2(1 \cdot 3)^{-} \\
43 \cdot 0(1 \cdot 3) \\
45 \cdot 9(3 \cdot 6)\end{array}$ & $\begin{array}{l}36 \cdot 2(2 \cdot 9) \\
53 \cdot 3(2 \cdot 9)^{\star \star} \\
62.9(3.4) \\
64 \cdot 9(3 \cdot 1) \\
87 \cdot 7(6 \cdot 4)\end{array}$ & $\begin{array}{l}47 \cdot 9(2 \cdot 0)^{\star} \\
46 \cdot 9(1 \cdot 2) \\
52 \cdot 6(2.9)\end{array}$ & $\begin{array}{r}98(5 \cdot 9)^{\star \star} \\
101(5 \cdot 6)^{\star \star} \\
108(3 \cdot 7)^{\star \star}\end{array}$ \\
\hline
\end{tabular}

Indices: mean (SE). Comparison of EE and EI between groups ${ }^{\star} \mathrm{P}<0.05,{ }^{\star \star} \mathrm{P}<0.01$.

undertaken to identify those variables which were independently related to energy expenditure. Several potential confounding variables were identified - age, sex, gestation, weight, type of feeding, ventilation and activity. Factors independently related to energy expenditure were: postnatal age $(P<0.01)$; milk feeds rather than TPN $(P<0.01)$; and physical activity $(\mathbf{P}<0.05)$.

\section{Discussion}

Energy expenditure and nutrient utilisation of the healthy preterm infant may be influenced by many factors, including postnatal age, activity, nutrition and growth, thermal environment, and state of health. ${ }^{10}$ Until recently the overall effect of these variables on the energy expenditure of the sick preterm infant has been uncertain. In this study of energy expenditure of low birthweight infants during the first five days of life, energy expenditure was found to be lower, and respiratory quotient higher, in parenterally fed ventilated infants compared with milk fed spontaneously breathing infants, this difference being most significant during the immediate postnatal period.

There have been few previous studies of energy expenditure in ventilated low birthweight infants during the immediate postnatal period. Hazan and colleagues, measuring energy expenditure before and after the administration of surfactant, reported similar levels of energy expenditure and also demonstrated considerable inter- and intra-individual variation. ${ }^{11}$
The measurements of carbon dioxide production in our study were comparable with those reported by Lucas and colleagues. ${ }^{12}$ The energy expenditure data obtained by Mayfield during the clinical evaluation of an indirect calorimeter for infants were significantly higher, with expenditures of $50-75 \mathrm{kcal} / \mathrm{kg} /$ day being recorded during the first days of life. ${ }^{13}$ Support for our findings is provided by the study of Mitton and colleagues, who found that turnover rates, and therefore energy expenditure, were lowest in the most sick infants, using stable isotope methodology for measurement of protein turnover in sick ventilated preterm infants during the first days of life. ${ }^{14}$

Low estimates of energy expenditure of ventilated infants using indirect calorimetry can occur if respiratory gases bypass the endotracheal tube, because this produces an underestimate of carbon dioxide production and oxygen consumption. Similarly, inspiratory gas leaks will result in an overestimate of oxygen consumption. In our study most infants were intubated with shoulder endotracheal tubes, and leakage was relatively rare and usually minimal. If a major leak occurred, indirect calorimetry was not performed. In the study by Lucas and colleagues leakage of carbon dioxide was either not detected or was less than $5 \%$ of total carbon dioxide production. ${ }^{12}$

The measurements of $\mathrm{PaO}_{2}$ and $\mathrm{PaCO}_{2}$ taken before and after calorimetry were recorded as indirect measurements of changes in the respiratory gas pools. ${ }^{15}$ The measurements of $\mathrm{PaO}_{2}$ and $\mathrm{PaCO}_{2}$ taken at the beginning and at the end of calorimetry were not significantly different, suggesting that measurements of oxygen consumption and carbon dioxide were not influenced by changes in respiratory gas pools.

There is a large volume of nutritional information on factors which may influence the energy expenditure of spontaneously breathing infants, ${ }^{210}$ but a similar analysis of ventilator dependent infants has not been reported before. Multiple regression analysis incorporating age and sex of infant, maternal antenatal steroids, surfactant treatment, type of feed, and artificial ventilation as discrete variables, and weight, gestation, and activity scores as continuous variables identified age $(P<0.01)$, type of feeding $(P<0.01)$, and physical activity $(P<0.05)$ as factors which had an independent effect on energy expenditure. Previous studies have shown that there is an increase in energy expenditure in healthy preterm infants during the first seven to 10

Table 5 Oxygen consumption $\left(\mathrm{VO}_{2}\right)$, carbon dioxide production $\left(\mathrm{VCO}_{2}\right)$, and respiratory quotient $(\mathrm{RQ})$ during days $1-5$

\begin{tabular}{|c|c|c|c|c|c|c|c|c|c|}
\hline \multirow[b]{2}{*}{ Day } & \multicolumn{3}{|c|}{$\mathrm{VO}_{2}(\mathrm{~mL} / \mathrm{kg} /$ minute $)$} & \multicolumn{3}{|c|}{$\mathrm{VCO}_{2}(\mathrm{~m} / \mathrm{kg} /$ minute $)$} & \multicolumn{3}{|l|}{$R Q$} \\
\hline & 1 & 2 & 3 & 1 & 2 & 3 & 1 & 2 & 3 \\
\hline $\begin{array}{l}1 \\
2 \\
3 \\
4\end{array}$ & $\begin{array}{l}4.9(0.2) \\
4.9(0.3) \\
5.6(0.4) \\
5.6(0.4) \\
5.9(0.3)\end{array}$ & $\begin{array}{l}5.9(0 \cdot 2)^{\star \star} \\
6 \cdot 4(0 \cdot 2)^{\star \star \star} \\
5 \cdot 9(0 \cdot 2) \\
6 \cdot 1(0 \cdot 2) \\
6 \cdot 3(0.5)\end{array}$ & $\begin{array}{l}7 \cdot 0(0 \cdot 2)^{\star \star} \\
6 \cdot 8(0 \cdot 2)^{\star} \\
7 \cdot 5(0 \cdot 3)\end{array}$ & $\begin{array}{l}4.9(0.3) \\
4.8(0.3) \\
5.6(0.4) \\
5.5(0.4) \\
5.8(0.3)\end{array}$ & $\begin{array}{l}5 \cdot 8(0 \cdot 2)^{\star \star} \\
6 \cdot 2(0 \cdot 3)^{\star \star} \\
5 \cdot 7(0 \cdot 2) \\
6.0(0 \cdot 2) \\
6.9(0.5)\end{array}$ & $\begin{array}{l}6.3(0.3) \\
6.3(0.2) \\
7.0(0.5)\end{array}$ & $\begin{array}{l}1.00(0.03) \\
0.97(0.03) \\
1.01(0.05) \\
0.99(0.04) \\
0.98(0.05)\end{array}$ & $\begin{array}{l}0.98(0.02) \\
0.98(0.03) \\
0.98(0.03) \\
0.98(0.02) \\
1.10(0.03)\end{array}$ & $\begin{array}{l}0.91(0.02) \\
0.93(0.03) \\
0.93(0.03)\end{array}$ \\
\hline
\end{tabular}


Table 6 Activity scores (modified Bruck activity scales ${ }^{9}$ )

\begin{tabular}{lll}
\hline $\begin{array}{l}\text { Group 1 } \\
(n=23)\end{array}$ & $\begin{array}{l}\text { Group 2 } \\
(n=34)\end{array}$ & $\begin{array}{l}\text { Group 3 } \\
(n=18)\end{array}$ \\
\hline $0.35(0.05)$ & $0.58(0.07)$ & $0.74(0.1)$ \\
\hline
\end{tabular}

Indices: mean (SE). Group $1 v 2 v 3 ; \mathbf{P}<0.01$.

days of life. ${ }^{16}$ This trend was apparent in each of our study groups, but over the short study period the increase was not significant. The energy expended by physical activity by healthy preterm infants has been estimated at $5 \cdot 3 \%$ of total energy expenditure. ${ }^{9}$ Using a modified version of Bruck's activity scales as a measure of physical activity, we demonstrated that activity was significantly less in those infants who were both ventilated and intravenously fed. We did not find a significant correlation between ventilatory index and energy expenditure. This agrees with the findings of Hazan and colleagues, ${ }^{11}$ who also studied infants during the first days of life, but contrasted with the strong association between oxygen consumption and ventilatory index reported in older infants receiving ventilatory support for bronchopulmonary dysplasia. ${ }^{17}$ Our finding that total energy expenditure in sick ventilated infants is lower than that of healthy spontaneously breathing infants of similar age is probably related to the latter expending energy on physical activity, maintaining body temperature, and diet induced thermogenesis. Differences in basal metabolism between the three groups were not determined in this study.

Respiratory quotients were higher in intravenously fed infants, with nearly half of these infants having an RQ greater than $1 \cdot 0$; the carbohydrate intake correlated with the $R Q$. An RQ greater than 1.0 indicates that excess carbohydrate is being converted to fat, this process generating an increase in carbon dioxide production. ${ }^{18}$ The effects of large carbohydrate loads on carbon dioxide production in adults have been widely reported..$^{19} 20$ Increased carbon dioxide exacerbates hypercapnia in patients with chronic lung disease and there have been reports of artificially ventilated patients being unable to be weaned until carbohydrate calories were reduced. ${ }^{21}$

This study has confirmed that low birthweight infants, especially sick ventilated infants, are in negative energy balance during the first days of life, and by day 5 they may not yet be receiving sufficient nutritional support to achieve equivalent intrauterine growth rates. ${ }^{22}$ Attempts to meet the energy needs immediately after birth with glucose as the sole energy source may be inadvisable, especially in infants with respiratory disease. Although there is a tendency to introduce enteral feeds earlier in those infants, this will not be tolerated by the sickest infants, and in those infants a mix of intravenous glucose and fat may not only reduce carbon dioxide production but also offer other nutritional benefits. ${ }^{23}$

We gratefully acknowledge support for this study from the Chest, Heart and Stroke Association (Scotland), the Scottish Home and Health Department, and Cow \& Gate Nutricia.

1 Lucas A, Morley R, Cole TJ, Gore SM, Davis JA, Bamford MFM, et al. Early diet in preterm babies and development status in infancy. Arch Dis Child 1989; 64: 1570-8.

2 Morgan JB, Kovar IZ. The low birth weight infant and parenteral nutrition. Nutrition Res Rev 1992; 5: 115-29. 3 Saini JR, MacMahon P, Morgan JB, Kovar IZ. Early parenteral feeding of amino acids. Arch Dis Child 1989; 64: $1362-6$.

4 Lucas A. Does early diet program future outcome? Acta Paediatrica Scandinavica 1990; 365 (suppl): 58-67.

5 Forsyth JS, Crighton A. An indirect calorimetry system for ventilator dependent very low birthweight infants.

6 Shortland GJ, Fleming PJ, Walter JH. Validation of a portable indirect calorimetry system for measurement of energy expenditure in sick preterm infants. Arch Dis Child 1992; 67: 1207-11.

7 Weir JB de V. New methods for calculating metabolic rate with special reference to protein metabolism. I Physiol (Lond) 1949; 109: 1-9.

8 Enhorning G, Shennan A, Possmayer F. Prevention of neonatal respiratory distress syndrome by tracheal instillation of surfactant: a randomized clinical trial. Pediatrics 1985 ; 76: $145-53$.

9 Freymond D, Schutz Y, Decombaz J, Micheli JL, Jequier E. Energy balance, physical activity, and thermogenic effect of feeding in premature infants. Pediatr Res 1986; 20: 638-45.

10 Brooke OG. Energy expenditure in the fetus and neonate: Sources of variability. Acta Pediatrica Scandinavica 1985; 319: 128-34.

11 Hazan J, Chessex P, Piedboeuf B, Bourgeois M, Bard H, Long W. Energy expenditure during synthetic surfactant replacement therapy for neonatal respiratory distress syndrome. F Pediatr 1992; 120: S29-33.

12 Lucas A, Nohria V, Roberts SB. Measurement of carbon dioxide production rate in sick ventilated premature infants. Biol Neonate 1987; 51: 138-43.

13 Mayfield SR. Technical and clinical testing of a computerized indirect calorimeter for use in mechanically ventilated neonates. Am f Clin Nutr 1991; 54: 30-4.

14 Mitton SG, Calder AG, Garlick PJ. Protein turnover rates in sick, premature neonates during the first days of life. Pediatr Res 1991; 30: 418-22.

15 Mines AH. Carbon dioxide carriage by blood. In: Johnson LR, ed. Essential medical physiology. New York: Raven Press, 1992: 273-5.

16 Sauer PJ, Dane HJ, Visser HKA. Longitudinal studies on metabolic rate, heat loss, and energy cost of growth in low birth weight infants. Pediatr Res 1984; 18: 254-9.

17 Billeaud C, Piedboeuf B, Chessex P. Energy expenditure and severity of respiratory disease in very low birth weight infants receiving long-term ventilatory support. $\mathcal{f}$ Pediatr 1992; 120: 461-4.

18 Acheson KJ, Schutz Y, Bessard T, Ravussin E, Jequier E. Nutritional influences on lipogenesis and thermogenesis after a carbohydrate meal. Am $\mathcal{F}$ Physiol (Endocrinol Metab 9) 1984; 246: E62-70.

19 Askanazi J, Rosenbaum SH, Hyman AI, Silverberg PA, Milic-Emili J, Kinney JM. Respiratory changes induced by the large glucose loads of total parenteral nutrition. fAMA 1980; 243: 1444-7.

20 Covelli HD, Black JW, Olsen MS, Jerome F, Beekman MD. Respiratory failure precipitated by high carbohydrate loads. Ann Intern Med 1981; 95: 579-81.

21 Dark DS, Pingleton SK, Kerby GR. Hypercapnia during weaning. A complication of nutritional support. Chest 1985; 88: 141-3.

22 Shaw JCL. Growth and nutrition of the very preterm infant. $B M \mathcal{A}$ 1988; 44: 984-1009.

23 Heird WC. Parenteral feeding. In: Sinclair JC, Bracken $\mathrm{MB}$, eds. Effective care of the newborn infant. Oxford: Oxford University Press, 1992: 141-60. 